for viruses. Dr. Rivers discussed the retrograde and the evolutionary vital theories, and also the nonvital autocatalytic ideas of several students of the problem. He pointed out that the weakness of these conceptions is that viruses may not all be similar, and such a plastic group may well embrace all the forms mentioned.

\section{Venereal Disease in the United States}

The United States Public Health Service reports that treatment and laboratory facilities and services in the control of venereal disease increased between 30 and 85 per cent during the last fiscal year ending June 30, 1939. Every State Department now has a separate division or sub-division for the control of venereal disease. Approximately 103,000 persons were discharged from clinics as cured or the disease arrested in 1939, as compared with 78,000 in the previous year. Persons treated for the first time numbered 305,000 and the number of treatments administered was $8,000,000$. Training centres for physicians and nurses in venereal disease control have been established in nine universities.

\section{Earthquakes in Peru}

AN earthquake on the night of May 24 did considerable damage to the towns of Lima and Callao in Peru. A dry dock and pier at Callao were damaged, part of a building belonging to the College of St. Thomas Aquinas collapsed, and hundreds of other buildings were destroyed. Two aftershocks of some severity followed on May 25. As a result of the shocks it is estimated that there were 300 dead and 1,500 injured in the two towns, though detailed information is lacking owing to the temporary severing of communications with the area as a result of the earthquakes. Although the whole of Peru is subject to minor earthquakes and earth tremors, the present epicentre appears to be farther north than the most seismic district in Peru, namely, the regions around Arequipa. On January 8, 1725, an earthquake with its epicentre near Arequipa caused widespread destruction and damage was caused in Lima. In the present instance no news has yet been heard of Arequipa. Slight tremors, possibly sympathetic with the above, have also been felt at Guayaquil in Equador.

\section{Agricultural Work for University Students}

A scheme has been prepared by the Ministry of Agriculture and Fisheries to encourage students at universities and colleges to undertake agricultural work during the summer vacation. Recruiting bureaux have been set up at the principal universities, where full particulars of the scheme and application forms may be obtained. Volunteers will receive at least the appropriate minimum wage-rates fixed by the local agricultural wages committee. This particular scheme is intended for men only, but the Minister also appeals to women students who are willing to spend four weeks or more on the land to join the Women's Land Army Auxiliary Force, particulars of which may be obtained from the local county secretary of the Women's Land Army, or from the headquarters at Balcombe Place, Balcombe, Sussex.

\section{The Parliamentary and Scientific Committee}

At a meeting of the Parliamentary and Scientific Committee at the House of Commons on May 22 it was decided in view of the grave situation to hold regular weekly meetings in future to examine all ways by which a greater application of scientific knowledge could be applied to the conduct of the War in its various aspects and to bring these matters to the immediate notice of the appropriate Ministers. The first of these meetings was held at the House of Commons on May 29.

\section{Announcements}

Ar the anniversary meeting of the Linnean Society of London held on May 24 the following were elected. officers for the year 1940-41: President, Dr. E. S. Russell ; Treasurer, Mr. Francis Druce ; Secretaries, Mr. I. Henry Burkill (botany), and Dr. Malcolm Smith (zoology). The new members of the Council are Mr. J. S. L. Gilmour, Mr. J. R. Norman, Dr. C. F. A. Pantin, Dr. E. S. Russell and Major F. C. Stern.

Specimens of a rare nickel-iron sulphide mineral, hravoite from Mill Close Mine, Derbyshire, have en presented to the Department of Mineralogy of une British Museum (Natural History) by Prof. W. G. Fearnsides. This is the first known occurrence of the mineral in the British Isles.

THE attainment of the Government's ploughing-up objective in Great Britain and Northern Ireland was announced on May 23 in the House of Commons by the Minister of Agriculture and Fisheries. The total additional grassland ploughed amounts in England and Wales to $1,542,236$ acres-an excess of 42,000 acres over the target programme of $1 \frac{1}{2}$ million acres. When the figures for Scotland (about 222,000 acres) and Northern Ireland (about 270,000 acres) are added, a grand total of 2,034,236 acres is obtained.

THe Association for Education in Citizenship is organizing a Summer School at Lady Margaret Hall, Oxford, during August 7-14, the subject for discussion being "Education for Effective Democracy". Further information can be obtained from the Association for Education in Citizenship, 10 Victoria Street, London, S.W.1.

The Brighton Summer School in Animal Biology will be held during August 3-15 at the Municipal Technical College, Brighton, under the direction of Prof. L. E. S. Eastham. Further information can be obtained from Mr. F. H. Toyne, Education Officer, 54 Old Steine, Brighton. 